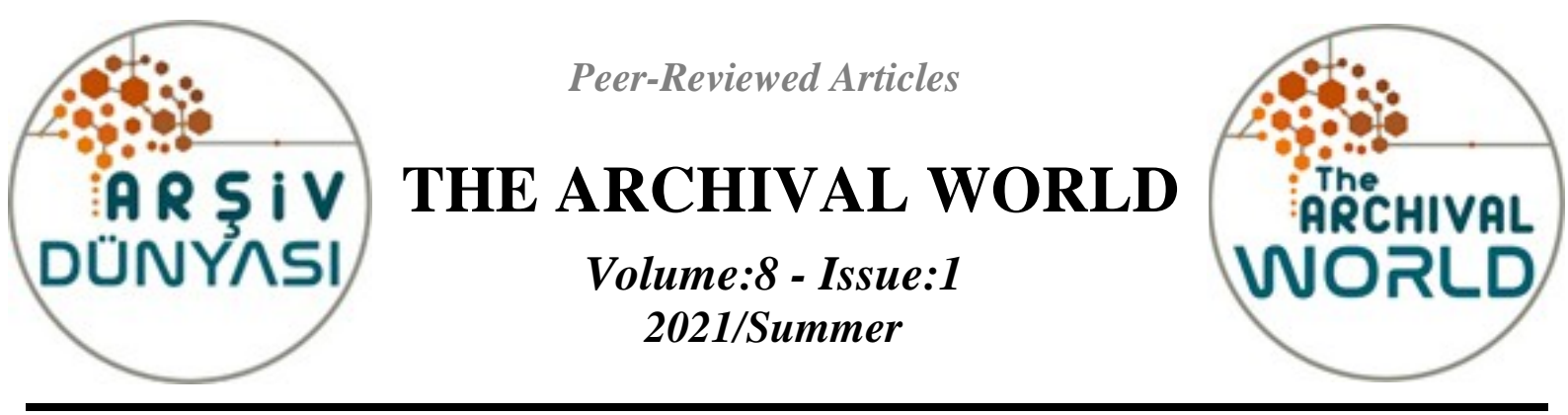

Doi: $10.53474 / a d .938257$

\title{
REFERENCE SERVICES IN ARCHIVES: A MATTER OF PRESTIGE
}

\author{
Assoc. Prof. Dr. Burçak ŞENTÜRK \\ Marmara University, Faculty of Arts and Science \\ Information and Records Management Department \\ burcaksenturk@gmail.com \\ https://orcid.org/0000-0001-5780-8324
}

\begin{abstract}
Archival services have a different place among information services. The main factors determining this place are the nature of archival material, the archive users and the mission and the usage purposes of the archives. Besides, it is essential to meet the expectations of users of archival services, as in all types of services. A very difficult and long term effort is carried out in the archival management process before the archival material is put into use. The process in which this effort is reflected on the user is reference services. Reference services are a matter of prestige for archives. For this reason, it is crucial that reference services are carefully designed and managed with a user-oriented perspective.
\end{abstract}

Keywords: Reference Services, Archives, Reference Archivist

\section{ARŞIVLERDE REFERANS HIZZMETLERİ: BIIR SAYGINLIK MESELESİ}

ÖZ

Bilgi hizmetleri içerisinde arşiv hizmetlerinin farkl bir yeri vardır. Bu yeri belirleyen başlıca hususlar arşiv malzemesinin doğası, arşiv kullanıcıları, arşivin misyonu ve kullanım amaçlarıdır. Bunun yanında her hizmet türünde olduğu gibi arşiv hizmetlerinde de kullanıcıların beklentilerinin karşılanması çok önemlidir. Arşivsel yönetim sürecinde, arşiv malzemesinin kullanıma sunulmasindan önce zorlu ve uzun soluklu bir uğraş gerçekleştirilmektedir. Bu uğraşın kullanıcıya yansıdığ süreç referans hizmetleridir. Bundan dolayı referans hizmetleri arşivler için bir saygınlık sorunudur ve referans hizmetlerinin kullanıcı odaklı bakış açısı ile dikkatlice tasarlanıp yönetilmesi gereklidir.

Anahtar Kelimeler: Referans Hizmetleri, Arşivler, Referans Arşivcisi

Geliş Tarihi/Received: 17.05.2021

Kabul Tarihi/Accepted: 14.06.2021 


\section{INTRODUCTION}

It is possible to divide the basic functions that make up the archival management process into two groups as 'back desk services' and 'front desk services'. While appraisal, accessioning, arrangement, description, preservation and security functions constitute the back desk processes; access, reference services, user relations and marketing functions constitute the front desk services. Back desk services are carried out to make archival material available for users and front desk services include interaction and communication with the user. For this reason, these functions are essential in terms of the prestige and image of the archival institution, creating positive awareness, archival quality and user satisfaction.

An ongoing dilemma has been experienced over the mission of archives from the past to the present. Some experts argued that preserving archival material is the top priority, while others argued that is the making available archival material is the top priority. The main reasons for this dilemma to arise are the basic properties of archival material and its uniqueness. However, today, it is possible to say that the mission of archives has changed from being material oriented to user oriented.

Reference services are the showcases of archives as part of the front desk services. They are a matter of prestige for archives because due to excellent reference services the use of archival material is encouraged, satisfied users are acquired, the quality of the back desk services is increased, and positive awareness can be created in the field of archives in general.

The focus of the study is on traditional reference services rather than online reference services. In this context, it should be noted that online reference services are more related to online access. Traditional reference services are still important, and up to date in the age we live in. This can be explained as follows: The importance of digitization and online access in archives is indisputable. Especially in the digital age we are in. However, many experts advocate that it is vital to examine the original archival material in an archival environment to understand better the purpose of the archives, the archival material and to reveal better studies. Examining the original archival material in an archival environment is also important for archives and archival material to complete its mission. At this point, reference services come into play in archives and hence the strategic importance of well planned and user-oriented reference services.

Within the scope of the study, essential and important points of archival reference services are examined by giving examples from the literature. In this context, the aim of the study is to reveal the important processes and points that should be considered during the design of traditional archival reference services.

\section{THE NATURE OF ARCHIVAL REFERENCE SERVICES}

Archival reference services are the processes of bringing the user together with the archival material. In order to plan and manage them in line with their strategic importance, it is necessary first to understand their nature and importance.

Reference services is the general name given to the facilities and services that enable the researcher to use the archives and its records once access to them is approved. Enabling that use involves the archivist not only in helping resarchers to identify, select, and read records but also in such activities as providing a suitable environment for research, answering mail and telephone enquiries and providing reprographic services to assist researchers to obtain copies of records (McCausland, 1993, p.273). 
Researcher services is a broader term that is better suited to the range of assistance that archivists should provide, including encouraging research use of their hodings, actively counselling and assisting researchers, making records available, and analyzing and measuring research use to help determine future program directions and priorities (Deartyne, 1993, p.174).

Some experts in archival literature emphasized the importance of making archival material available and all kinds of services and processes for this purpose in various studies.

The third pillar of archival service is to make archival holdings available for use. Once the archivist has acquired archival materials; arranged and described them according to standards; and stored them in a secure environment so that they are safe from harm, she can, and should, open the doors and invite the public in (Millar, 2010, p.183).

The principle goal of an archival reference service program is to facilitate the use of materials in the custody of an institution. Crucial to its success is a commitment by the institution to the basic concepts that govern other service-oriented institutions. These include stating clearly what is expected of the patron and the archivist, and treating each researcher seriously and fairly. It also means that those in charge of a reference program must be sensitive to the psychological stresses involved in constant daily contact with the public (Kepley, 1988, p.161).

The ultimate goal of archival work is to identify and preserve information that is put to use by people for some deliberate purpose. The value of the records archivists so carefully collect and preserve depends on the importance of their information, and that, in turn, depends on who uses the records and for what purposes (Dearstyne, 1987, p.77).

In the planning and management of reference services in archives, apart from the type of archive, the mission of the archive, its main goals, objectives, the quality and quantity of the archival material, and the usage habits of the users should be carefully considered. Although all processes for the user seem to be secondary due to the importance of the archival material they offer for archives, it is a fact that user and reference services are/should be important for archives, based on the logic that information is valued as it is used (Şentürk, 2021, p.73).

\section{ESSENTIALS OF EXCELLENT ARCHIVAL REFERENCE SERVICES}

In the archival literature, various studies have been carried out on reference services. In these studies, the importance of reference services, the reference archivist were emphasized, and how the reference environment should be were discussed.

Richard Cox (1992, pp.139-147) has determined seven basic elements to provide adequate reference services especially for the institutional archives. These elements are as follows:

1. Maintenance of a suitable research facility,

2. Clearly written set of researcher rules and regulations,

3. Management of researcher application,

4. Entrance and exit interviews of researchers,

5. A policy for the manner in which it will handle other than in-person research visits,

6. Reprographic service, and

7. The institutional archivist should view the reference area as a means to study the organization's use of information and as a result, the potential role of the archives.

The archives must provide opportunity for research in the records it holds. The archives should be open for research use on a regular and stated schedule. It should provide adequate space and facilities for research use and should make its records available on equal terms of access to all users who should abide by its rules and procedures. Any restrictions on access should be defined in writing and should be carefully observerd ( McCarthy, 1989, p.45). Today, the concept of quality service has 
been replaced by the excellent service, which is a more assertive concept. In this context, the main goal of archival reference services should be to achieve excellence.

The complexity of the management process of reference services has previously been emphasized. With the concept of excellence, the situation becomes more difficult. In order to overcome this difficulty and provide an excellent reference service, it will be the right method to reveal the basic elements of the process. In this context; within the scope of the study 'essentials of excellent archival reference services' are examined under the headings as:

$\checkmark$ The reference environment

$\checkmark$ The process of reference and the

$\checkmark$ The reference archivist

\section{The Reference Environment}

The reference environment is a very delicate matter to design as one of the essentials of excellent archival reference services. The reference environment is mostly related to the physical elements and the research room in traditional archival reference services. The reference environment can be expressed as physical places where studies are carried out on the original archival material.

Millar (2010, p.187), describes the reference environment in the archives as follows: No matter who comes into the reference room, the archivist needs to create a supportive service environment, which means investing in resources such as technology, publications, equipment and supplies. Desk and chairs, light and heat, access to nearby refreshment facilities: The basics of adequate service must be a given. The institution's finding aids-either print or electronic- should be available for easy use in the reference area, and a collection of standard reference materials should be maintained, including atlases, dictionaries, encyclopedias, local histories and relevant periodicals or journals.

The reference area, often called the search room, is a controlled sector within the institution in which users can consult archival materials in an atmosphere conducive to study. The reference area should have the following features (Cook, 1999, pp.107-108):

$\checkmark \quad$ The entrance door should be clearly labelled.

$\checkmark$ Opening times should be shown on or near the entrance door.

$\checkmark$ Reference staff should have their own desks, marked with labels such as 'Search Room Officer on Duty' or 'Enquiries'.

$\checkmark \quad$ The room should be clean, tidy and uncrowded, with furniture arranged so that staff can supervise the research area from a single point.

$\checkmark \quad$ Silence should be maintained by both researchers and staff. If possible, a separate reference area should be used for meetings or interviews.

$\checkmark \quad$ The location of lists and finding aids, including reference books, should be clearly marked.

$\checkmark$ Archival documents should not be left in the research area, nor should they be left unattended on desks in the search room. If researchers have to leave the room, they should advise the staff of their absence and ask them to watch the documents or return them to the document issue area for safekeeping.

$\checkmark \quad$ The area where requests for documents are submitted and the documents themselves are issued to and returned by researchers should be clearly marked.

Two critical points should be taken into account in designing the reference environment in the first place. First of all, the security of the archival material should be ensured. Then, a physically comfortable environment should be created where the users can work on the archival material for long hours or days. In the second place, the design of the reference environment should be worked on, especially in line with the feedback obtained from the users. Because it is important to make the 
reference environment attractive to ensure that new generation users are constantly coming to the archive. This is also a requirement of a user-oriented service approach.

\section{The Process of Reference}

The process of reference refers to the time when users interact with the institution and the archivist, and is one of the most important indicators of the quality of the archive service. During this time, it should be ensured that everything goes right and smoothly.

The points where information should be collected during the planning of the reference process can be listed as (Williams, 2006, p.136):

$\checkmark$ Mission and purpose of the organisation,

$\checkmark$ Resource base of the archives (or other reference) service,

$\checkmark$ Nature of client base,

$\checkmark$ Priority given to reference services in relation to other records/archives functions,

$\checkmark$ Nature of holdings, primary and secondary sources,

$\checkmark$ Nature and quality of finding aids,

$\checkmark$ Degree of staffing and supervision required and

$\checkmark$ Level of demand

Paul Conway (1986, p.399), in his cult article titled 'Facts and frameworks: An approach to studying the users of archives' suggests focusing on the following three topics related to reference services in archives:

"...... archivists should measure and evaluate three elements of reference services: the quality of archival programs and services is assessed in terms of how well archivists understand the information needs of their users and how well the programs and services are able to meet those needs they are intended to serve.; the integrity of archival programs and services is assessed in terms of how well archivists balance their responsibilities to enhance use while preserving the information in archival materials.; and the value of archival services and programs is assessed in terms of the effects of use on individuals, groups, and society as a whole."

There are some points should be considered for the success of the reference process, and for the users to be satisfied with this process. Within the scope of this study, the important points regarding the reference process were determined as follows:

$\checkmark$ The magical term of the process of archival reference service is equality. All users should be treated equally.

$\checkmark$ The needs and demands of the users should be well understood, and users should be assisted at all times.

$\checkmark$ A system should be developed that can respond to the demands of users without interruption and continuously.

$\checkmark \quad$ In the archival reference process, finding aids are the most critical tools for users and archivists. For this reason, the up-to-dateness and usefulness of finding aids should be questioned regularly.

\section{The Reference Archivist}

The most crucial element of the 'service-specific marketing mix elements' is the person that is the service provider. In this context, the most strategic aspect of archival reference services is the reference archivist. Reference archivists who do their job with enthusiasm are the ones that determine the fate of reference services. Therefore, they have a great responsibility. 
Archivists serving researchers interact between their materials and the researchers. They ought to be as helpful as possible in assisting researchers. This requires the archivist to have command of the finding aids and/or other access tools and general familiarity with the records themselves, including their origin, the function that produced them or resulted in their creation, the state of their arrangement and usability, and the information they contain. It also requires an ability to understand researchers and their needs and an ability to deal patiently, politely, and effectively with people (Dearstyne, 1993, p187).

The best reference archivists are those who combine a knowledge of the materials they administer with an ability to deal with the general public. In spite of the good intentions that must permeate a reference program, factors exist that limit an archives' ability to provide complete access to its materials. These include preservation concerns, the amount of staff time available, records that are not yet processed, the extent to which the institution should do research for the patron, and the sensitivity of the information which some records may contain (Kepley, 1988, p.162).

Archivists have, in the last three decades, developed descriptive, preservation and recordkeeping standards, constructed online databases and expanded the reach of our professional associations to address not just historical archives care but the broad sweep of records and archives management. We should not forget these archival successes. But archivists also have to lift ourselves out of our analogue environment and focus more effort on forging a new path - if we can keep playing with that metaphor - to reposition our world, including archives, archival institutions and archival practitioners, more strategically for the future. To do this, we need to take a step back and remember that we are not sitting on the apex of achievement but on the crest of a wave (Millar, 2017, p.60).

As Millar said, archivists have made significant progress in the technical issues of archiving. However, archivists must constantly improve themselves in line with the requirements of the new age. This becomes more important in the reference process. Archivists should get off their desks, and be more active and social. They should become more interactive with users and help them understand that archives and archival material can be as entertaining as it is educational. In addition to these, reference archivists should not forget that they need to balance between preserving the material and making it available. Richard Valpy (2016, p.154) explains the mission of reference archivists as follows:

"Archivists have to do more than just try to convince people that we are useful. We have to become useful with the real problems of records and information management in the 21 st century. To do this, we need to reach beyond our professional and institutional boundaries and work directly with the public, whose interests we serve."

\section{IMPROVING ARCHIVAL REFERENCE SERVICES}

In addition to the essentials of excellent archival reference services, strategies for the development of reference services should also be outlined in archival institutions. These strategies can also be called as key points.

Dearstyne (1987, p.78) mentions about six areas where analysis and new approaches are needed for a better archival reference service: 1.tracking and studying research use, 2. interpreting and reporting on the significance of that use, 3.promoting increased use, 4.emphasizing use as a means of garnering program support, 5.reaching out to the researcher community as a partner in dealing with difficult archival problems, and 6.expanding the concept of reference service to a broader notion of researcher service or public service. 
Battly and Wright (2012, p.112) presented three elements that should be examined to improve the reference service as:

1. Our current users: Who are they, and how satisfied are they with our services?

2. Our potential users: Why aren't they here? How could we be helping them? What are the obstacles and opportunities?

3. How does the way we describe and promote our archives and services bias the possible views of our holdings and their potential use?

In this study 3 main strategic processes as effective reference interview, analysing reference services and user education programs have been emphasized to acquire an excellent archival reference services.

\section{Effective Reference Interview}

It should be recognized that the main actors in the development of reference services are users. Besides, studying primary resources like archival material needs more assistance. Therefore, it is crucial to communicate effectively with users in this process. The aim here is to hear the demands and needs of the users correctly. For this purpose, reference interview is an important development tool for archival reference services.

With a successful reference interview;

$\checkmark$ Users' needs can be determined,

$\checkmark$ User satisfaction and dissatisfaction points can be determined,

$\checkmark$ Advice and suggestions can be received from users,

$\checkmark$ Users can be given more detailed information about the archival material they request, and

$\checkmark$ Users can be supported in their study.

The reference interview title is frequently encountered in the reference services sections of basic archives studies. The reference interview is an integral part of reference services, and experts have made valuable determinations about reference interview.

Reference interview is a conversation between an archivist and a researcher designed to give the researcher an orientation to the use of the materials, to help the researcher identify relevant holdings, and to ensure that research needs are met (Pearce-Moses, 2005, p.337).

The reference interview provides the researcher with essential information relating to the archives, for example, access to the archives' facilities and collections, opening hours, rules for the use of archives, the arrangement of finding aids, other archival collections that may be of assistance, and guidelines for citations and reproduction of records (McCausland, 1993, p.289).

Archival reference services should not only be seen as the use of archival material and the acquisition of digital data about those who use the archival material. In archival reference services, the reference archivist must command the success and output of the user's research process. Cox (1992, pp.138139) expresses this situation as follows.

"Archival reference and access are an area that has begun to be rethought and restudied by the archival profession in recent years. Archivists have realized that they actually know little about research use within their reference rooms. For decades, archivists tended to evaluate and assess research use by numbers (how many, when, and patterns in heavy and light use) and types of researchers (scholars, genealogists, local historians, amateur historians, and institutional staff) rather than by the nature, success, and significance of their research." 


\section{Analysing Reference Services}

It is vital to collect and analyze data about users, use, and access to material for excellent reference services. Many managerial strategic decisions can be taken in line with the analysis results during information services.

With the data obtained in the reference process in the archives, important determinations are made in many topics, especially the user profile, expectations, demands and suggestions, and the usage process of the material.

Dearstyne (1993, pp.190-191), determined some questions need to be answered during the reference service process as follows:

$\checkmark$ Who uses the records?

$\checkmark$ How do researchers learn about the existence of the repository and its holdings?

$\checkmark$ What are the purposes of use?

$\checkmark$ What specific subjects are being researched?

$\checkmark$ What records are used?

$\checkmark$ What is the intensity of use-the time spent in research use in relation to the quantity of records used?

$\checkmark$ How rich and significant was the information gleaned from the record?

$\checkmark$ How will the information be disseminated?

$\checkmark$ If the information is disseminated, what type of impact can it be expected to have?

$\checkmark$ How helpful are the repository's finding aids and other services?

An essential point in analysing reference services is to perform the necessary analyses regularly. Traditional satisfaction surveys applied by most archives are not enough today. More useful and effective analysis methods should be determined. It should not be forgotten that institutional development and strengthening will be provided by analyzing the reference service.

\section{User Education Programs}

Ericson (1990, p.118), argued that users should be trained to serve a better audience, with the following words:

"One of the great myths of our profession, and one of our most debilitating misconceptions, is that archives exist simply to serve scholars. In fact, if most of us were forced to justify our existence through the numbers of scholars we served, we would be out of business. There are other groups that would benefit from using archival materials, but we must first educate them as to how and why. In other words, we may choose to be fussy about whom we serve, or we may complain about how we are underutilized. But we may not do both."

User education programs are one of the topics on the archives' agenda in recent years. With user education programs, users get information about archival material, finding aids and the process of access. In this way, more successful studies that will provide maximum benefit from archival material can be produced. In addition, users are satisfied with the quality of reference services; as a natural result of this, they get positive opinions about archives and archival material, and beyond that, the quality of reference services increases.

User education programs to be planned and implemented in archives should have three fundamental pillars. These are (Şentürk, 2021, pp.111-112): 
$\checkmark$ Giving information about the collection of the archive,

$\checkmark$ Providing general information about the archival process (characteristic features and importance of archival material, digitisation and etc.), and

$\checkmark$ Provision of information about how the user should use the material, the research principles in the archive, and the use of printed and electronic finding aids.

\section{CONCLUSION}

Reference services are essential processes that serve the mission of archives management. These are the moments when archives and archival material meet with the target audience. The mission of reference services has more than one aspect. Reference services are the showcases of the archives. The moment of truth stays, and the faith of the prestige of the archives will be determined in this process.

Reference services are pioneers in recognition of archives. It is one of the main actors in ensuring the satisfaction of archive users. One of the most critical elements of the 21 st century archives portrait is reference services.

Recently, archives provide significant support to education and become active in the education process has drawn attention to reference services. At this point, the necessity of making reference services attractive for the new generation has emerged. It is evident that the most crucial factor affecting the success of reference services in archives is the reference archivist. The reference environment and the reference process are the secondary factors. These three basic elements should be emphasized for excellent reference services to be designed and implemented in the eyes of the user.

The most important thing that recent archival studies emphasize is the strategic importance of archives for people, societies, memory and the building of the future. In addition to the fact that archival material is so rich and valuable, the only thing missing is that the reputation of the archives in the eyes of people and society can not reach the required level. The most crucial factor that can eliminate this deficiency is excellent reference services in the eyes of the user.

\section{REFERENCES}

Battley, Belinda and Alicia Wright. (2012). Finding and addressing the gaps: two evaluations of archival reference services, Journal of Archival Organization, 10(2), 107-136.

Conway, P. (1986). Facts and frameworks: An approach to studying the users of archives. American Archivist, 49, 393-407.

Cook, Michael. (1999). Managing Archives: Managing Public Sector Records, A Study Programme. UK: IRMT.

Cox, Richard J. (1992). Managing Institutional Archives. New York: Greenwood Press.

Dearstyne, Bruce W. (1993). The Archival Enterprise. Chicago: ALA.

Deartyne, Bruce W. (1987). What's the use of archives. A challenge for the profession, American Archivist, 50, 76-87.

Ericson, Timothy L. (1990). Preoccupied with our own gardens: outreach and archivists, Archivaria, $31,114-122$. 
Kepley, David R. (1988). Reference service and Access, in Managing Archives and Archival Institutions. James G. Bradsher (Ed.). London: Mansell, 161-173.

McCarthhy, Paul. (1989). Archives Assessment and Planning Workbook. Chicago: The Society of American Archivists.

McCausland, S. (1993). Access and Reference Services. in Keeping Archives, Judith Ellis (Ed.), Melbourne: Thorpe, 273-305.

Millar, Laura A. (2010). Archives: Principles and Practices, London: Facet Publishing.

Millar, Laura. (2017) On the crest of a wave: transforming the archival future, Archives and Manuscripts, 45(2), 59-76.

Pearce-Moses, Richard. (2005). A Glossary of Archival and Records Terminology, Chicago: The Society of American Archivists.

Schellenberg, T.R. (1956). Modern Archives: Principles and Techniques, Chicago: The Society of American Archivists.

Şentürk, Burçak. (2021). Arşivcilik: Geçmişin İzlerinden Geleceğin Pusulalarına. İstanbul: Hiperyayın.

Valpy, D. Richard. (2016). From missionaries to managers: making the case for a canadian documentary heritage commission. Archivaria, 82, 137-163.

Williams, Caroline. (2006). Managing Archives: Foundations, Principles And Practice, Oxford: Chandos Publishing. 